\title{
Application Responsibility Accounting to Sustainable Development in Vietnam Manufacturers: An Empirical Study
}

\author{
Tran Trung Tuan \\ National Economics University (NEU), Ha Noi, Viet Nam
}

\begin{abstract}
Vietnamese enterprises continue to face serious difficulties due to the influence of financial crisis in the past years. One of efficent management tools at present in the process of decision-making in management, operation, and control of the administrator's business operations, strengthen development of Vietnamese enterprises is Responsibility Accounting (RA). However, responsibility accounting in general is a very new content in both theoretical and practice in Viet Nam. Therefore, determining theoretical framework of responsibility accounting and the level of responsibility accounting application enables enterprise administrators to make a decision exactly, promptly and comprehensively as content of important argument. This research aims to identify the development of responsibility accounting, from four primary elements of initial accounting responsibilities (Don \& Marynne, 2005) developed into seven elements (Gharayba, Fatena, Debi, Ma’Moon, \& Nasar, 2011) and developed into 43 scales matching seven elements (Hanini, 2013) and some new items in this paper. The research also identifies the level application of responsibility accounting according to seven elements of responsibility accounting is medium or high application level and has solutions to improve level of responsibility accounting application in Vietnam's textile and garment enterprises. This is the scientific basis for Vietnam enterprises in general and Vietnam's textile and garment enterprises in particular have a successful application of responsibility accounting to improve performance. In this paper, SPSS (Statistical Product and Service Solutions) 22 was used to collect and analyse data by distributing 64 questionnaires on managers and head of departments from Vietnamese textile and garment manufacturers.
\end{abstract}

Keywords: responsibility accounting, textile and garment, elements, administrator, performance, responsibility center

\section{Introduction}

One of the crucial tools for manager nowadays in making decision of managing, operating, and controlling business activities is viewed as system of responsibility accounting. Responsibility accounting helps manager to control and evaluate activities conducted by departments of a firm and evaluate different levels of management responsibilities. Then, this also helps manager to have valuable information in making decisions for achieving general objective, strengthen sustainable development of enterprises. Presently, Vietnamese firms have conducted restructuring process after financial crisis and coped with intensive competitions. Vietnamese

Tran Trung Tuan, Ph.D., CPA, School of Accounting and Auditing (SAA), National Economics University (NEU), Ha Noi, Viet Nam.

Correspondence concerning this article should be addressed to Tran Trung Tuan, National Economics University, 207 Giai Phong Road, Ha Noi, Viet Nam. 
firms also have coped with challenges in evaluating outcomes of these firms. In the dimension of this paper, theoretical framework of responsibility accounting and level of application of responsibility accounting at Vietnamese firms have been shown, based on the results of in-depth interviews of management from Vietnam's textile and garment firms.

\section{Literature Review}

There are many different views about the responsibility accounting, according to different purposes, professional researchers or administrators in enterprises with different angles of RA in the business different now. However, there is no unified concept of responsibility accounting:

This new approach to accounting and reporting is the development of an accounting system designed to control expenditures, directly relating the reporting of expenditures to the individuals in the company organization who are responsible for their control. This system results in the preparation of accounting statements for all levels of management, designed primarily so that they can be effectively used by the operating people as a tool in controlling their operations and costs. (Higgins, 1952)

Responsibility accounting is considered as an important control system and represents a source of information that facilitates decision making process in short and long ranges (Sarkar \& Yeshmin, 2005).

Responsibility accounting as a control device emphasizes responsibility centers. These are subunits of an organization under a specific manager'control and hence have direct responsibility for its activities (Fowzia, 2011).

Responsibility accounting closely is related to cost accounting. One of the important goals of responsibility accounting is the control of cost at the basic levels of supervisor. This means that not all expenses are controlled at the management level of divisional director, it means that expenses are controlled at any level which raise expenses and accepted (Kellogg, 1962).

RA is the accounting system which is acknowledged through different responsibility centers in the entire organization and reflects results, performance of each center by revenue and cost items (Horngren, Foster, \& Datar, 2000).

According to Atkinson, Banker, Kaplan, and Young (2001), responsibility accounting is the accounting system functions as collection, summarization, and report on accounting information related to costs, income, and operating data by each scope of responsibility or unit in organization. Such system shall provide information so as to evaluate responsibility and performance of each manager. RA shall create reports containing objects which are able or unable to control for a management level.

Responsibility accounting is the management method in order for design of accounting system so as to obtain control efficiency through the direct relationship between accounting report and the head in the organizational structure of company at all management levels (Meda, 2003).

Responsibility accounting connects the personal performance report with the heads of the different management levels to determine the level of obtaining goal of management levels, and responsibility centers. These responsibility centers have different goals and use resources of company to obtain goals (Rajbi, 2004).

From the point of view of responsibility accounting, the author can draw some general nature of the liability of accounting as follows:

Firstly, responsibility accounting is a basic content management accounting to generate financial information systems and non-financial related to the actual operation and planning, used to control activities 
and assess the performance of each division, head of department in the enterprise.

Secondly, responsibility accounting related to the organizational structure of the enterprise is decentralized and explicit authorization. A basic requirement for the implementation of responsibility accounting is the existence of a realiablly organizational structure. The complete line of power should be determined before responsibility accounting is done. The managers are at every level, who is decentralized consistent with his management responsibilities in the business.

Thirdly, responsibility accounting provides managers with information to control business activities of subordinate managers. RA controls responsibility by passing individual responsibility for the achievement of financial targets and non-financial enterprises. RA assigns responsibility, sets the powers and responsibilities for each department or individual and uses system of indicators, performance reporting to control the operation and connect the parts and units within the enterprise to ensure businesses operating activities according to plan.

Fourthly, responsibility accounting can be based on decentralized organization to divide the responsibility centers consistent with the organizational structure or accounting shall be based on the content in order to divide the contents specific details. In each content, RA uses a mixture of cost accounting methods and methods of results evaluation, particularly modern methods for recognition, measurement, and evaluation of performance achieved in business department.

Fifthly, responsibility accounting establishes a reporting system providing financial and nonfinancial information for administrators to control operation according to defined objectives.

Through the synthesis of views on different aspects, in general, responsibility accounting is a information system based on decentralization and authorization to the administrators, decentralization to the administrators, department within organization using a mixture of cost accounting methods and evaluation methods to record success, measure, evaluate operating results achieved in the organization in order to provide financial and nonfinancial information for managing the appropriate powers as assigned and responsibilities in parts, the center responsibility for controlling parts and units in operation now in the right direction intended.

Considering the perspective and approach of the organizational structure and the level of decentralization, the liability of accounting is divided into the responsibility center.

Responsibility center shall be part of the organization, where executives responsibility department operating results of its parts. Accordingly, based on the organizational structure and degree of decentralization, enterprise system centers corresponding responsibility. Currently, most researchers believe that there are four types of responsibility center that is responsibility for the cost center, revenue center, profit center, and investment center.

Considering the views and approaches of content, liability accounting has the following elements:

According to Don and Marynne (2005), responsibility accounting included four essential elements:

(1) Responsibility is defined;

(2) Performance measures are established;

(3) Performance is measured;

(4) Individuals are rewarded.

The basic elements work together in the order of the following diagram: 


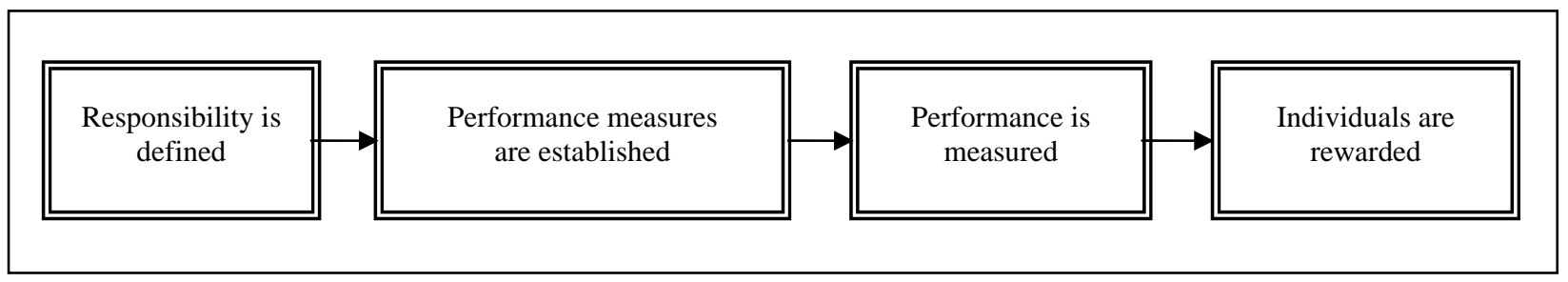

Figure 1. Basic elements of responsibility accounting. Source: Don and Marynne (2005).

From four basic elements as above, in their study, Gharayba et al. (2011) developed into seven elements and other authors as Hanini (2013)...used in research on accounting charge liability, responsibility accounting has the following elements:

(1) RA shall divide the organizational structure of the enterprise to its various responsibility centers based on the specific characteristics of such enterprises;

(2) Responsibility accounting decentralizes power to the administrator at the center of responsibility with clear authority and administrator shall be responsible for the achievement of the central responsibility. The administrator should be authorized with power matching activities at the center of responsibility and accountability necessary to make decisions related to the responsibilities of the central and executive responsibilities treatment to achieve planned results;

(3) Responsibility accounting shall divide the costs and revenues to the central responsibility as possibilities and limit the power of the center. Also, responsibility accounting shall determine and calculate direct costs, indirect costs, revenue, and internal transfer prices between central responsibility appropriately and accurately to identify clear responsibilities;

(4) Responsibility accounting implementation links between the estimates with actual results at the center of responsibility. Accountants are responsible for encouraging all employees of each center done drafting to ensure appropriate cost estimates, feasibility and can achieve the overall goals of the business;

(5) Responsibility accounting estimater is used to control and measure results through the comparison with the actual results of each responsibility center;

(6) Responsibility accounting prepares a report to analyze the difference of actual results with the estimates to determine who shall be responsible for the difference. All managers have to analyze the reasons for the difference between the actual results achieved and estimates made. Accounting reports shall be classified according to different levels of responsibility;

(7) Responsibility accounting sets up an incentive system which has a close relationship with the estimation results at the center of responsibility to limit undesirable disparities and promote good differences, and determine who is responsible for the difference in order to encourage employees to improve their achievement and the overall success of the entire enterprise.

Content approach is suitable for the development of responsibility accounting. Initial accounting responsibilities have four primary elements (Don \& Marynne, 2005) developed into seven elements (Gharayba et al., 2011). Later, Hanini (2013) developed into 43 scales matching seven elements. In the next section, researchers will use content-based approach (the approach of seven elements) and the use of (Hanini, 2013) 43 scales was developed based on seven elements to perform analysis the application of responsibility accounting in Vietnam's textile and garment firms. 


\section{Research Methods}

\section{Measuring Scale of Variables}

Research on using the measurement scale included 43 items on measuring the level of responsibility accounting application of Hanini (2013) and developing more new items on measurement is the measurement on method of Balanced Scorecard (two items) to achieve the researching target. In order to research on 43 these variables new variables on developing more are realiable, suitable to Vietnam's textile and garment firms.

\section{The Population of the Study}

The population of the study is represented by Vietnam's textile and garment firms of the sample which was represented by a random sample and consists of the general managers and the managers of deparment...72 questionnaires were distributed but 64 were retrieved with 89\%. To support for the survey research, the Likert scale is used. The format of five-point Likert scale is: 1 = "very low"; 2 = "low"; 3 = "medium"; 4 = "high"; 5 = "very high".

Table 1

The Description of the Sample-Job Title*

\begin{tabular}{llllll}
\hline & Frequency & Percent & Valid percent & Cumulative percent \\
\hline \multirow{4}{*}{ Valid } & Board of director & 15 & 23.4 & 23.4 & 23.4 \\
& board of managers & 17 & 26.6 & 26.6 & 50.0 \\
& Head of department & 16 & 25.0 & 25.0 & 75.0 \\
& Foreman & 16 & 25.0 & 25.0 & 100.0 \\
& Total & 64 & 100.0 & 100.0 & \\
\hline
\end{tabular}

Note. *The description of the sample about job title.

Table 2

The Description of the Sample-Age ${ }^{*}$

\begin{tabular}{llllll}
\hline & & Frequency & Percent & Valid percent & Cumulative percent \\
\hline \multirow{4}{*}{ Valid } & From 30-39 years & 12 & 18.8 & 18.8 & 18.8 \\
& From 40-49 years & 33 & 51.6 & 51.6 & 70.3 \\
& More than 50 years & 19 & 29.7 & 29.7 & 100.0 \\
& Total & 64 & 100.0 & 100.0 & \\
\hline
\end{tabular}

Note. *The description of the sample about age.

Table 3

The Description of the Sample-Practical Experience*

\begin{tabular}{llllll}
\hline & & Frequency & Percent & Valid percent & Cumulative percent \\
\hline \multirow{4}{*}{ Valid } & From 5-10 years & 8 & 12.5 & 12.5 & 12.5 \\
& From 11-20 years & 21 & 32.8 & 32.8 & 45.3 \\
& More than 20 years & 35 & 54.7 & 54.7 & 100.0 \\
& Total & 64 & 100.0 & 100.0 & \\
\hline
\end{tabular}

Note. $*$ The description of the sample about practical experience.

\section{Analysing Data Technique}

There are total of 64 collective and valid responses. After collecting data, according to the part and the group of these data in the questionaire, they are changed and encoded in Microsoft Excel. Then, SPSS 22.0 is applied to analyse these data. 


\section{Research Questions}

This research is designed to examine level of responsibility accounting application in the Vietnam's textile and garment enterprises. The study will answer the main questions:

- How is level of responsibility accounting application in Vietnam's textile and garment enterprises like?

- What should be done to improve level of responsibility accounting application in Vietnam's textile and garment enterprises?

\section{The Hypotheses of the Study and the Items of the Hypotheses}

Based on the theoretical frame and the previous studies, the following hypotheses were formed:

\section{The first hypothesis:}

HO1: Vietnam's textile and garment firms do not divide the organizational structure into centers of responsibility.

This hypothesis is tested through the items:

Table 4

The Items of the First Hypothesis

\begin{tabular}{ll}
\hline $\mathrm{N}$ & Item \\
\hline 1 & There is an organizational structure divided into administrative units according to the nature of the activity. \\
3 & There is clarity in dividing the work in the administrative units. \\
4 & There is a clear description to the centers of responsibility. \\
5 & There is a coordination and clarity in the relation between the centers of responsibility. \\
6 & Every center of responsibility has one type of activity. \\
7 & The operations inside the center of responsibility are characterized by homogeneity. \\
\hline
\end{tabular}

\section{The second hypothesis:}

HO2: Vietnam's textile and garment firms do not authorize the managers of responsibility centers with clear powers.

This hypothesis is tested through the items:

Table 5

The Items of the Second Hypothesis

\begin{tabular}{ll}
\hline $\mathrm{N}$ & Item \\
\hline 8 & The manager is told his duties in the center of responsibility. \\
9 & The manager of the center is granted appropriate authorities to do his work. \\
10 & There is a description and identification of the responsibilities and the authorities of every job. \\
11 & The employees of the center of responsibility have the needed expertise to do their work in the center. \\
12 & The manager of the center is given enough time to do their work. \\
13 & The employees' accountability suits their responsibilities. \\
\hline
\end{tabular}

\section{The third hypothesis:}

HO3: The costs and the revenues are not distributed to the centers of responsibility according to each center's capability and powers in Vietnam's textile and garment firms.

This hypothesis is tested through the items: 
Table 6

The Items of Third Hypothesis

\begin{tabular}{ll}
\hline $\mathrm{N}$ & Item \\
\hline 14 & All the revenues regarding the center of responsibility are identified and recorded. \\
15 & All the costs regarding the center of responsibility are identified and recorded. \\
16 & There is clarity in the system of comparing the revenues with the costs of the center of responsibility. \\
17 & There is a clear policy regarding the indirect costs' distribution to the centers of responsibility. \\
18 & There is a clear and identified system of the costs distribution and the revenues. \\
\hline
\end{tabular}

\section{The fourth hypothesis:}

HO4: Vietnam's textile and garment firms do not link previously the estimated budgets with the centers of responsibility.

This hypothesis is tested through the items:

Table 7

The Items of the Fourth Hypothesis

\begin{tabular}{ll}
\hline $\mathrm{N}$ & Item \\
\hline 19 & $\begin{array}{l}\text { A clear and a realistic objective is identified for every center of responsibility and complies with the performance } \\
\text { standards. }\end{array}$ \\
20 & Necessary adjustments on the estimated budgets of the centers are carried out wherever there is a need. \\
21 & The estimated budgets are prepared regarding every center separately. \\
22 & The firm trains the employees of the centers and encourages them to achieve these centers' objectives. \\
23 & All the employees of the center participate in preparing the center's budget according to their job. \\
24 & Enterprises use financial scale to prepare budget. \\
25 & Enterprises use non-financial scale to prepare budget. \\
\hline
\end{tabular}

\section{The fifth hypothesis:}

HO5: The estimated budgets are not used for control and performance evaluation in Vietnam's textile and garment firms.

This hypothesis is tested through the items:

Table 8

The Items of the Fifth Hypothesis

\begin{tabular}{l}
$\mathrm{N} \quad$ Item \\
\hline $26 \quad \begin{array}{l}\text { Comparing the employees' actual performance with the planned one in every center facilitates the communication } \\
\text { between the administrative levels. }\end{array}$ \\
$27 \quad \begin{array}{l}\text { Comparing the employees' actual performance with the planned one in every center helps in evaluating the employees' } \\
\text { performance. }\end{array}$ \\
$28 \quad \begin{array}{l}\text { Comparing the employees' actual performance with the planned one in every center provides appropriate information in } \\
\text { the proper time. }\end{array}$ \\
$\begin{array}{l}\text { Comparing the actual performance of the employees supports the policies of control. } \\
30 \quad \text { Comparing the employees' actual performance with the planned one in every center aims to identify the deviations and } \\
\text { consequently identifies who is the responsible. }\end{array}$ \\
\hline
\end{tabular}

\section{The sixth hypothesis:}

HO6: Vietnam's textile and garment firms do not prepare reports through which deviations of the actual performance of the planned one were analyzed.

This hypothesis is tested through the items: 
Table 9

The Items of the Sixth Hypothesis

\begin{tabular}{ll}
\hline $\mathrm{N}$ & Item \\
\hline 31 & Reports of the center of the responsibility are prepared to measure the center's performance. \\
32 & The manager and the employees of the center of responsibility participate in designing the form of the performance report. \\
33 & The reports regarding the center of responsibility care of the financial aspects. \\
34 & The reports regarding the center of responsibility care of the non-financial aspects. \\
35 & The reports measure the performance of each center separately. \\
36 & The information of the reports is linked with employees who are responsible for them. \\
37 & The deviations mentioned in the report are analyzed and studied. \\
38 & Methods to treat the reasons of the mentioned deviations in the reports are set where it is possible. \\
\hline
\end{tabular}

\section{The seventh hypothesis:}

HO7: There is no system of incentives that links the results of the centers of responsibility in Vietnam's textile and garment firms.

This hypothesis is tested through the items:

Table 10

The Items of the Seventh Hypothesis

\begin{tabular}{ll}
\hline $\mathrm{N}$ & Item \\
\hline 39 & Enterprises's administration grants incentives to the employees who achieved the objectives of the planned objectives. \\
40 & Enterprises's administration grants moral incentives to the employees who achieved the objectives. \\
41 & The incentives suit the employee's responsibility in the center. \\
42 & The incentives contribute to increasing the employees' efficiency who work in enterprises. \\
43 & There is a satisfaction by the employees towards the incentives system. \\
44 & The employees are rewarded and motivated regarding objective basis and efficiency. \\
45 & There is a periodical reconsideration of the system of incentives. \\
\hline
\end{tabular}

\section{Research Results}

\section{Testing the Reliability of Scale}

Cronbach's alpha was used to measure the reliability of scale. The research result shows that Cronbach's alpha is 0.918 , which indicates a high level of internal consistency for all scales with this specific sample.

Table 11

Reliability Statistics

\begin{tabular}{ll}
\hline Cronbach's alpha & N of items \\
\hline 0.918 & 45 \\
\hline
\end{tabular}

\section{EFA Analysis}

From the result, with $\mathrm{KMO}=0.738(>0.5)$ and sig. $=0.000(<5 \%)$, it can reject the hypothesis that correlation matrix is homogeneous matrix. It means that the variables are intercorrelated and satisfy the condition in EFA analysis.

Extraction method of the study is Principal Component Analysis. The Total Variance Explained table shows that with eigenvalue $>1$, there are only seven factors extracted. With cumulative $\%$ of rotation sums of squared loadings being 81.997, it means that the fluctuation of figures is explained by seven factors. Rotation method varimax with Kaiser Normalization shows that, there are seven components. 
Table 12

KMO and Bartlett's Test

\begin{tabular}{lll}
\hline Kaiser-Meyer-Olkin measure of sampling adequacy & & 0.738 \\
\hline \multirow{3}{*}{ Bartlett's test of sphericity } & Approx. chi-square & $3,550,280$ \\
& $\mathrm{df}$ & 0.990 \\
& Sig. & 0.000 \\
\hline
\end{tabular}

Table 13

Total Variance Explained

\begin{tabular}{|c|c|c|c|c|c|c|c|c|c|}
\hline \multirow[b]{2}{*}{ Component } & \multicolumn{3}{|c|}{ Initial eigenvalues } & \multicolumn{3}{|c|}{ Extraction sums of squared loadings } & \multicolumn{3}{|c|}{ Rotation sums of squared loadings } \\
\hline & Total & $\begin{array}{l}\% \text { of } \\
\text { variance }\end{array}$ & $\begin{array}{l}\text { Cumulative } \\
\%\end{array}$ & Total & $\begin{array}{l}\% \text { of } \\
\text { variance }\end{array}$ & $\begin{array}{l}\text { Cumulative } \\
\%\end{array}$ & Total & $\begin{array}{l}\% \text { of } \\
\text { variance }\end{array}$ & $\begin{array}{l}\text { Cumulative } \\
\%\end{array}$ \\
\hline 1 & 16.424 & 36.498 & 36.498 & 16.424 & 36.498 & 36.498 & 6.253 & 13.895 & 13.895 \\
\hline 2 & 5.104 & 11.341 & 47.839 & 5.104 & 11.341 & 47.839 & 6.076 & 13.501 & 27.396 \\
\hline 3 & 4.304 & 9.565 & 57.404 & 4.304 & 9.565 & 57.404 & 5.893 & 13.096 & 40.493 \\
\hline 4 & 3.299 & 7.332 & 64.736 & 3.299 & 7.332 & 64.736 & 5.225 & 11.610 & 52.103 \\
\hline 5 & 3.134 & 6.965 & 71.701 & 3.134 & 6.965 & 71.701 & 5.123 & 11.385 & 63.488 \\
\hline 6 & 2.862 & 6.360 & 78.061 & 2.862 & 6.360 & 78.061 & 4.682 & 10.404 & 73.892 \\
\hline 7 & 1.771 & 3.936 & 81.997 & 1.771 & 3.936 & 81.997 & 3.647 & 8.105 & 81.997 \\
\hline
\end{tabular}

One-sample test was used to test hypotheses. Results of testing hypotheses are shown below:

Table 14

One-sample Statistics

\begin{tabular}{lllll}
\hline & $\mathrm{N}$ & Mean & Std. deviation & Std. error mean \\
\hline Organizational structure divided & 64 & 3.1496 & 0.96335 & 0.12042 \\
Authority divided & 64 & 2.8568 & 1.15541 & 0.14443 \\
Distribute cost and revenues & 64 & 3.3375 & 0.92642 & 0.11580 \\
Prepare estimates budget & 64 & 3.2790 & 1.00547 & 0.12568 \\
Use estimates budget & 64 & 3.2531 & 1.01434 & 0.12679 \\
Use reports & 64 & 3.1523 & 0.86041 & 0.10755 \\
Incentives system & 64 & 3.0067 & 0.92317 & 0.11540 \\
\hline
\end{tabular}

\section{One-sample Test}

Table 15

One-sample Test of Hypothesis

\begin{tabular}{llllllc}
\hline & \multicolumn{9}{c}{ Test value $=3$} \\
\cline { 2 - 7 } & & & Df & $\begin{array}{l}\text { Sig. } \\
\text { (2-tailed) }\end{array}$ & $\begin{array}{l}\text { Mean } \\
\text { difference }\end{array}$ & \multicolumn{2}{c}{$\begin{array}{c}\text { 95\% confidence interval of the } \\
\text { difference }\end{array}$} \\
\cline { 3 - 7 } & & & & & Lower & Upper \\
Organizational structure divided & 1.242 & 63 & 0.219 & 0.14955 & -0.0911 & 0.3902 \\
Authority divided & -0.992 & 63 & 0.325 & -0.14323 & -0.4318 & 0.1454 \\
Distribute cost and revenues & 2.914 & 63 & 0.005 & 0.33750 & 0.1061 & 0.5689 \\
Prepare estimates budget & 2.220 & 63 & 0.030 & 0.27902 & 0.0279 & 0.5302 \\
Use estimates budget & 1.996 & 63 & 0.049 & 0.25312 & -0.0002 & 0.5065 \\
Use reports & 1.416 & 63 & 0.162 & 0.15234 & -0.0626 & 0.3673 \\
Incentives system & 0.058 & 63 & 0.954 & 0.00670 & -0.2239 & 0.2373 \\
\hline
\end{tabular}


The result of one-sample test according to seven elements is in Sig. column (2-tailed): Sig. $<5 \%$ means that with the significance level 5\% (trust level 95\%), the author rejects $\mathrm{H}_{0}$, accepts $\mathrm{H}_{1}$; Sig. $>5 \%$ means that there is not enough basis to reject $\mathrm{H}_{0}$.

According to the data of collected samples, the result table shows that:

The Sig. values of elements: Organizational structure divided, authority divided, use reports, incentives system are greater than 0.05 . It means that the author has not enough basis to reject $\mathrm{H}_{0}$. The means of these elements of accounting responsibility are three, it shows that the level of these elements is medium.

The Sig. values of elements: Distribute cost and revenues, prepare estimates budget, use estimates budget is less than 0.05 . The means of these elements are greater than three, it shows that these elements have a high application level.

\section{Discussion}

Application responsibility accounting that provides information for decision-making processes of internal governance is the basis for developing internal resources, enhancing the competitiveness and improving the performance of Viet Nam firms in general and Vietnam's textile and garment enterprises in particular. To build and apply successfully responsibility accounting requires the latest synergies from the business itself, government, and educational institutions to promote the elements of responsibility accounting in Vietnam's textile and garment enterprises. Based on the research result, the author proposes the following solutions to improve level of application responsibility accounting:

Managers in Vietnam's textile and garment enterprises have to carry out the structural division of the enterprises into different responsibility centers on the natural features and administrating characteristics of their own business organization.

Based on the organizational structure, short- and long-term aims of Vietnam's textile and garment enterprises, the senior executives in the company should perform authorization for the managers of responsibility centers with explicit power to administrate. The manager must be responsible for results and performance of the responsibility centers.

Vietnam's textile and garment enterprises have to evaluate according to the aspects of Balanced Scorecard (BSC) including the financial and non-financial indicators to ensure comprehensiveness in effectively providing the information for administrators to improve business achievement.

Making responsibility accounting reports should use indicators according to four aspects of Balanced Scorecard to constitute accounting reports shall conform to the various responsibility centers.

Establishing rewarding system must also use the financial and non-financial indicators according to BSC to make a rewarding base to ensure objectivity, comprehensive system of rewarding.

The government should soon establish full legal of accounting responsibility for the enterprises in the economic market currently.

The state should build and plan for training of accounting staff in phases five, 10, 15 years, and longer strategic.

\section{Conclusions}

Responsibility accounting is the most important content of management accounting. Responsibility accounting provides the information for the administrators to make business decisions timely and correctly. The 
research has shown the development of responsibility accounting, from four primary elements of initial accounting responsibilities developed into seven elements and developed into 43 scales matching seven elements and two new items in this paper. Research has also clearly shown level of responsibility accounting application according to seven elements of responsibility accounting in Vietnam's textile and garment enterprises. After that, the research recommends solutions to improve level of responsibility accounting in Viet Nam firms. Since then, it is necessary for the Vietnam's textile and garment firms to encourage to use the other modern administrative accounting methods in its business as the application of the Balanced Scored Card (BSC) to improve performance, to strengthen sustainable development of Vietnam's textile and garment firms and Viet nam enterprises in the context of international integration further and broadly at present.

\section{References}

Atkinson, A. A., Banker, R. D., Kaplan, R. S., \&Young, S. M. (2001). Management accounting (3rd ed.). Prentice Hall.

Don, R. H., \& Marynne, M. M. (2005). Management accounting. McGraw-Hill Companies, Inc.

Fowzia, R. (2011). Use of responsibility accounting and measure the satisfaction levels of service organizations in Bangladesh. International Review of Business Research Papers, 7(5), 53-67.

Gharayba, Fatena, Debi, Ma'Moon, \& Nasar, A. (2011). The extent of applying the elements of responsibility accounting in the industrial shareholding companies and its effect on the company's profitability and operational efficiency. Administrative Sciences, 38(1), 219-234.

Hanini, A. (2013). The extent of implementing responsibility accounting features in the Jordanian banks. European Journal of Business and Management, 5(1), 217-229.

Higgins, J. A. (1952). Responsibility accounting (Vol. 12). Chicago, IL: The Arthur Andersen Cchronicle.

Horngren, C. T., Foster, G., \& Datar, S. (2000). Cost accounting: Managerial emphasis. Newdelhi, Prentice Hall of India Private Limited.

Kellogg, M. N. (1962). Fundamentals of responsibility accounting. National Association of Accountants. NAA Bulletin (pre-1986), 43(8), 5.

Meda, I. (2003). System of responsibility accounting in the Jordanian shareholding companies: Reality and hope. Journal of University of Damascus, 19(2), 317-363.

Rajbi, M. T. (2004). The administrative accounting (Vol. Dar Wael). Amman, Jordan.

Sarkar, J., \& Yeshmin, F. (2005). Application of responsibility accounting: Bangladesh perspective. The Cost and Management, 33(6), 82-88. 